\title{
The genomic evolution of human prostate cancer
}

\author{
$\mathrm{T}_{\text {Mitchell }}{ }^{* 1,2}$ and D E Neal ${ }^{3}$ \\ ${ }^{1}$ Department of Surgery, Academic Urology Group, University of Cambridge, Box 202, Level E9, Addenbrooke's Hospital, Hills \\ Road, Cambridge CB2 0QQ, UK; ${ }^{2}$ Wellcome Trust Sanger Institute, Wellcome Trust Genome Campus, Hinxton, Cambridge CB10 \\ 1SA, UK and ${ }^{3}$ Department of Oncology, University of Cambridge, Box 279, Addenbrooke's Hospital, Hills Road, Cambridge CB2 \\ OQQ, UK
}

Prostate cancers are highly prevalent in the developed world, with inheritable risk contributing appreciably to tumour development. Genomic heterogeneity within individual prostate glands and between patients derives predominantly from structural variants and copy-number aberrations. Subtypes of prostate cancers are being delineated through the increasing use of next-generation sequencing, but these subtypes are yet to be used to guide the prognosis or therapeutic strategy. Herein, we review our current knowledge of the mutational landscape of human prostate cancer, describing what is known of the common mutations underpinning its development. We evaluate recurrent prostate-specific mutations prior to discussing the mutational events that are shared both in prostate cancer and across multiple cancer types. From these data, we construct a putative overview of the genomic evolution of human prostate cancer.

\section{GENOMIC EPIDEMIOLOGY}

Prostate cancer is the most common cancer affecting men in the developed world, accounting for $25 \%$ of all new cases of cancer in males (Cancer Research UK, 2014). Of men diagnosed at the current time, $84 \%$ are predicted to survive 10 or more years. The incidence is strongly correlated with age, rates rising sharply from 166 per 100000 men at age 55-59 years to an overall peak of 800 per 100000 in the 75-79 years age group. Age-specific mortality rates also rise sharply from age 55, with the highest mortality rates in the $85+$ age group.

A landmark study examining the difference in the concordant occurrence of prostate cancer between monozygotic and dizygotic twins has revealed that $42 \%$ of prostate cancer may be explained by heritable risk-more than any other human cancer (Lichtenstein et al, 2000). This analysis has been updated with an expanded study population and more comprehensive statistical modelling to reveal an average genetic heritability of $58 \%$ (Hjelmborg et al, 2014). The first germline risk variant was discovered through the relationship of the BRCA2 gene and prostate cancer by the Breast Cancer Linkage Consortium. They estimated that heritable BRCA2 mutations confer a fivefold increased risk of prostate cancer. Similarly, BRCA1 mutations have also been shown to heavily predispose to prostate cancer, with both causing more aggressive disease and a worse prognosis (Eeles et al, 2014). Genome-wide association studies have expanded the discovery of germline genetic variants, in particular common low-risk polymorphisms, such that $\sim 33 \%$ of familial risk in the European ancestry population is now accounted for (Al Olama et al, 2014). Most susceptibility loci confer only a small increase in risk, with their effects acting multiplicatively.

\section{GENOMIC HETEROGENEITY}

Multiple tumour foci are commonly detected within prostates from patients with prostate cancer, and comparison of the genomic landscape in both inter-related and geographically distinct regions within prostates has revealed independent tumour origins in several studies (Svensson et al, 2011; Lindberg et al, 2013; Cooper et al, 2015). More recently, whole-genome sequencing of multiple metastatic sites from 10 tumours has revealed a common clonal origin containing $40-90 \%$ of total mutations and the majority of driver mutations (Gundem et al, 2015). These data imply that metastases originate commonly from only one tumour foci. Once a cell population has successfully metastasised there is strong evidence of on-going clonal evolution that has enabled both 'metastasis-to-primary' and 'metastasis-to-metastasis' re-seeding

*Correspondence: T Mitchell; E-mail: tommitchell@doctors.org.uk

Received 13 April 2015; revised 16 May 2015; accepted 20 May 2015; published online 30 June 2015 
(Gundem et al, 2015; Hong et al, 2015). It appears therefore that tumour heterogeneity increases as mutagenic processes continue to allow tumour clones to compete with one another within their micro-environment. This heterogeneity will only appear to decrease when an emergent tumour cell clone has mutated sufficiently to confer local or distant metastatic potential, or is able to survive cancer therapeutics. Phylogenetic trees can reconstruct the genomic archaeology of multi-focal tumours and may be described simplistically as linear, branched or independent as depicted in Figure 1. Many prostate cancers have been shown to have independent origins prior to development via a branching evolution stemming from a dominant clone.

\section{MUTATIONAL PROCESSES SHAPING THE CANCER} GENOME

Next-generation sequencing of somatic variants has enabled us to catalogue the mutations that have arisen within cancers. Roughly half of all prostatic tumours contain a fusion of E26 transformation-specific (ETS) family transcription factor genes with androgen-responsive promoters, most commonly transmembrane protease, serine 2 (TMPRSS2). At present this event defines the main molecular subtype of prostate cancer. Point mutations are believed to be less contributory in prostate carcinogenesis, with exome sequencing discovering a relatively low mutational frequency of 0.3-5 per Mb (Taylor et al, 2010; Barbieri et al, 2012; Grasso et al, 2012). In a saturation analysis of point mutations, small mutations across multiple tumour types, only four significantly mutated genes were discovered from the prostate cancer data set; SPOP (found in $10.1 \%$ of samples), TP53 (3.6\%), $\operatorname{ATM}(2.2 \%)$ and MED12 (3.6\%; Lawrence et al, 2014). When the prostatic data set was compared with cancer genes from the other 20 cancer types an additional two significantly mutated genes were detected, FOXA1 (2.9\%) and COL5A1 (2.2\%).

The frequency of copy-number aberrations (CNAs) in prostate cancer is significantly higher than that of point mutations, suggesting carcinogenesis and progression is primarily the result of chromosomal re-arrangements. CNA burden, defined as the percentage of the genome affected by CNAs, has been shown to correlate with tumour grade, biochemical recurrence and metastasis of prostate cancer, with metastatic samples containing an average CNA burden of $32 \%$, compared with $5 \%$ in primary

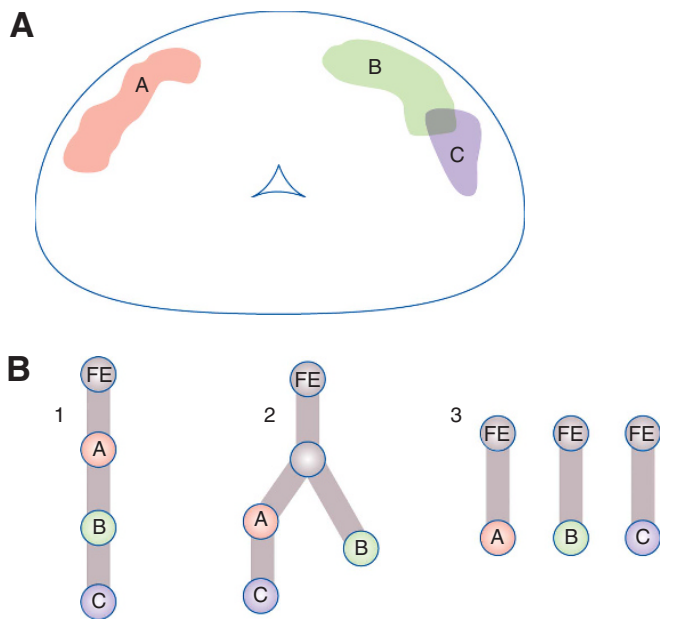

Figure 1. Genomic heterogeneity in multi-focal prostate cancer. (A) Schematic prostatic section with three foci of genomically distinct prostate cancer. (B) Possible evolutionary trees from fertilised egg (FE) to the three foci of prostate cancer: (1) linear evolution; (2) branched evolution; (3) independent evolution. disease (Baca et al, 2013; Hieronymus et al, 2014). CNA burden was also shown to be an independent prognostic biomarker for biochemical recurrence and metastasis after surgery and could further stratify the probability of recurrence in intermediate Gleason 7 prostate cancers (Hieronymus et al, 2014).

Curating CNAs to determine mechanistically which genes are driving oncogenesis remains challenging, and is especially true when large regions have been gained or lost. Whereas homozygous deletions often occur focally, loss of heterozygosity (LOH) and gains commonly affect large regions of the genome, and inferring which target gene within that region has conferred cellular growth advantage remains challenging. Pan-cancer analyses of somatic CNAs, examining the similarities and differences between diverse tumour types have added power to detect recurrent focal regions within the genome, many of which are thought not to contain known oncogenes or tumour suppressor genes (TSGs; Zack et al, 2013).

A recent pan-cancer analysis delineated mutational signatures contributing to the genomic landscape (Alexandrov et al, 2013). Furthermore, many of these signatures could be attributed to distinct mutational processes that are complicit in oncogenesis. For prostate cancer, signatures corresponding to aging and DNA mismatch repair (MMR) deficiency were detected, with predominant NpCpG to NpTpG substitutions. The contribution of an aging signature in prostate cancer comes is unsurprising given its age-related epidemiology. The DNA MMR deficiency signature is comprised of very large numbers of substitutions, together with small insertions/deletions of bases that are characteristic of cancers with defective DNA MMR and termed 'microsatellite instability'. Although germline variants of MMR genes are thought to predispose to prostate cancer (Raymond et al, 2013), somatic mutations have rarely been detected (Taylor et al, 2010). Despite these findings, decreased expression of MMR genes appears common (Chen et al, 2001) leading to the hypotheses that defects in as yet unknown genes are deregulating the MMR pathway.

The contribution of germline variants and mutational processes in the development of prostate cancer are summarised in the upper portion of Figure 2. Prostate cancer can be delineated according to ETS fusion status and their associated genomic aberrations, which are discussed in the subsequent section. Non-ETS-specific mutations may represent a convergent pathway to later stage disease and subsequent castrate resistance. Some of these mutations occur in genes closely involved in androgen receptor signalling and prostatic growth, whereas others occur in oncogenic pathways common to other cancer types. These pathways are discussed in turn in subsequent sections of this review.

\section{ETS FUSION-POSITIVE TUMOURS}

Recurrent gene fusions involving the oncogenic ETS transcription factors are found in roughly half of prostate-specific albuminscreened prostate cancers. Balanced structural re-arrangements, with specific abundance of ETS transcription factor gene fusions correlate with early onset prostate cancer as opposed to 'classical' elderly onset prostate cancer (Weischenfeldt et al, 2013; Steurer et al, 2014). The most common fusion links the TMPRSS2 androgen-responsive promoter and the transcription factor gene ERG (Tomlins et al, 2007). Many other androgen-related genes have since been discovered with fusion to other members of the ETS family including ets variant 1 (ETV1), ets variant 4 (ETV4), ets variant 5 (ETV5), and Friend leukaemia virus integration 1 (FLI1; Tomlins et al, 2009).

The inter-dependence of chained chromosomal re-arrangements, termed 'chromoplexy' has been commonly observed in ETS family fusion-positive prostate cancer and may disrupt multiple genomically distant cancer genes co-ordinately (Baca et al, 2013). 


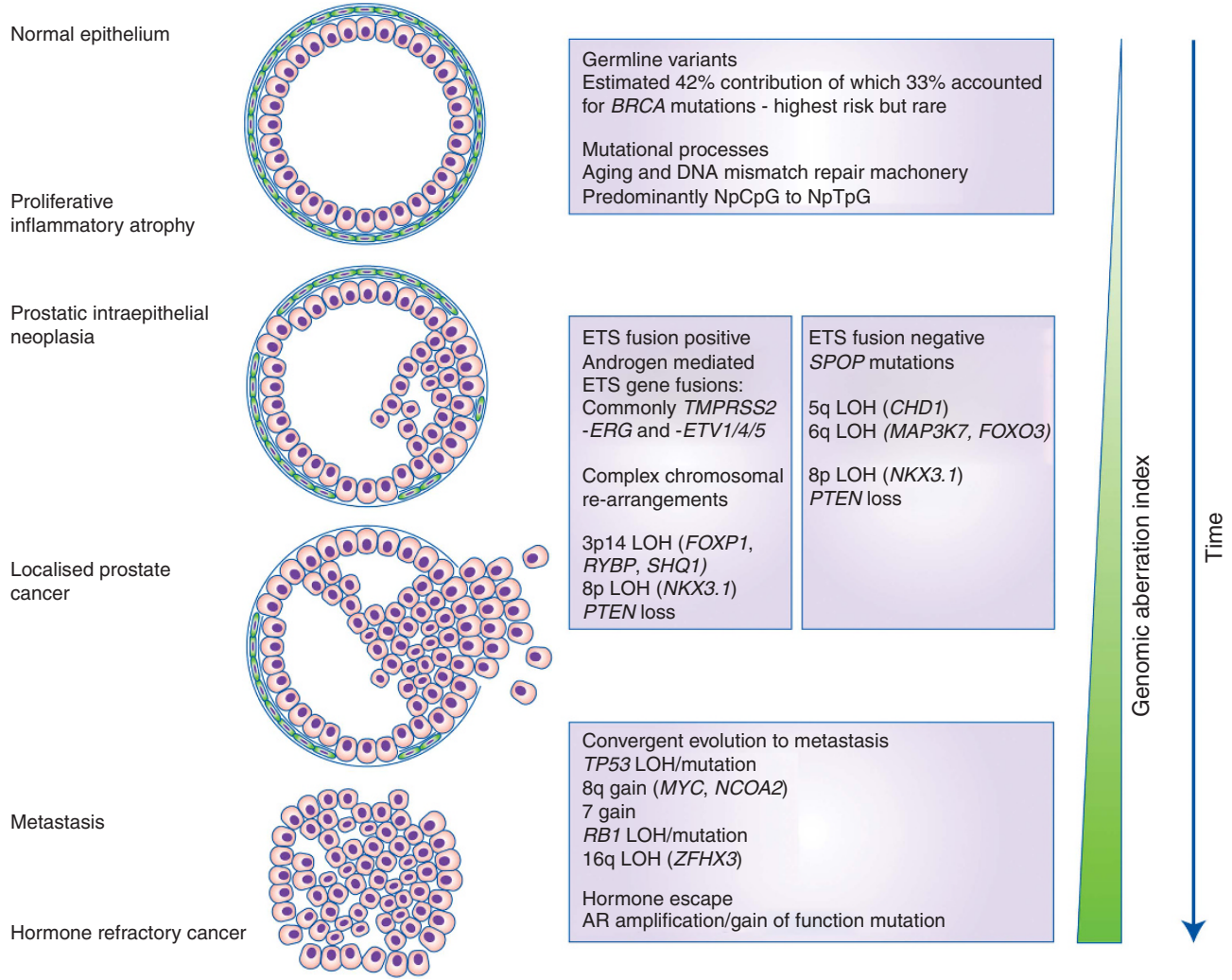

Figure 2. The putative genomic evolution of prostate cancer from normal epithelium to castrate-resistant, metastatic cancer. The pathological stages of prostate cancer are depicted on the left hand side of the figure, with corresponding genomic mutations that equate to cancer progression on the right. Cytobands are annotated according to which driver genes are most strongly implicated by the corresponding aberration.

The precise mechanism by which this occurs has yet to be elucidated fully, but it appears to represent an early or initiating step (Svensson et al, 2011; Weischenfeldt et al, 2013). Significantly, primary tumours may contain hundreds of rearrangements including translocations, deletions, insertions and inversions (Berger et al, 2011), contributing significantly to the overall CNA burden.

Whole-genome chromatin immunoprecipitation analyses have shown that ERG can bind to AR downstream target genes, and have suggested that ETS activation promotes epithelial-mesenchyme transition and tumour-invasive properties (Tomlins et al, 2007; Massie et al, 2011). This is supported through concordance analysis of TMPRSS2-ERG gene fusions in prostate adenocarcinoma and its precursor, prostatic intraepithelial neoplasia (PIN). Within the same tumour samples an association of ETS gene family fusions is seen with progression from PIN to cancer (Carver et al, 2009). The function of ETS fusions in cancer has been further explored in mouse models where ERG expression results in the development of PIN only in the context of the phosphoinositide-3kinase (PI3K) pathway activation (King et al, 2009), and combination with other lesions such as AR overexpression or PTEN loss leads to invasive adenocarcinoma (Carver et al, 2009). Multiple studies have also confirmed the correlation of ETS re-arrangements with PTEN inactivation as synergistic steps in the development of prostate cancer (Chen et al, 2005; Carver et al, 2009; King et al, 2009; Steurer et al, 2014).

Other aberrations associated with positive ETS status include focal deletions at 3 p14, representing an aggressive phenotype with early PSA recurrence (Krohn et al, 2013). This focal deletion is detected in $\sim 20 \%$ of primary and $30 \%$ of advanced prostate cancers (Williams et al, 2014). Three putative TSGs have been implicated in the deletion: FOXP1, RYBP and SHQ1, though the precise mechanism by which these deletions act is not yet clear (Taylor et al, 2010; Krohn et al, 2013).
The clinical significance of ETS re-arrangements in prostate cancer is still not fully resolved. Data are conflicting; ETS fusions have been reported as associated with both more aggressive and more indolent disease; most likely reflected by heterogeneity in study cohorts (Tomlins et al, 2009).

\section{ETS FUSION-NEGATIVE TUMOURS}

Speckle-type POZ protein $(S P O P)$ mutations and deletions in the $\mathrm{q}$ arm of chromosome 5 and 6 anti-correlated with ETS fusionpositive tumours (Figure 2). SPOP is an E3 ubiquitin ligase substrate-binding protein. Increased prevalence of these deletions with age has been shown to be strictly limited to ETS-negative cancers (Weischenfeldt et al, 2013). We discuss here known mechanisms of oncogenesis and the clinical implication of these mutations.

The most common SPOP point mutation in prostate cancer involves the substrate-binding cleft of the gene. This is mutated in $6-15 \%$ of tumours across multiple independent cohorts, and may define a distinct molecular subclass of ETS-negative prostate cancer (Barbieri et al, 2012; Grasso et al, 2012). Functional studies are now required to determine how these mutations relate to known and possibly new pathways of oncogenesis. A recent study of the changes in the ubiquitin landscape induced by prostate cancer-associated mutations in SPOP highlighted stabilisation of the oncogene $D E K$ and subsequent promotion of prostate epithelial cell invasion (Theurillat et al, 2014).

Deletions involving the chromodomain helicase DNA-binding protein 1 gene (CHD1) locus at $5 \mathrm{q} 21$ are associated with ETS fusion-negative tumours and occur in $10-25 \%$ of both primary and metastatic tumours (Barbieri et al, 2012; Grasso et al, 2012). Point mutations and rearrangements involving CHD1 have also been 
identified (Berger et al, 2011; Grasso et al, 2012). CHD1 alters gene expression possibly by modification of the chromatin structure. Prostate tumours with CHD1 deletion have been shown to contain an excess of both CNAs and intra-chromosomal re-arrangements (Baca et al, 2013).

Heterogeneous deletions of $6 \mathrm{q} 12-\mathrm{q} 22$ confer poor prognosis across multiple outcome parameters (Kluth et al, 2013; Williams et al, 2014). The mitogen-activated protein kinase kinase kinase 7 (MAP3K7) gene encodes TAK1 and is located at the peak of this broad region. As TAK1 has a role in the signalling transduction induced by TGF beta and morphogenetic protein, and controls a variety of cell functions including transcription regulation and apoptosis, it is reported as a strong candidate for the driver TSG within this region.

\section{PROSTATE DEVELOPMENT AND ANDROGEN} SIGNALLING

The homeodomain-containing transcription factor $\mathrm{Nkx3.1}$ is a putative tumour suppressor that has been shown to be a critical regulator of prostate epithelial differentiation and stem cell function in mouse models (Shen and Abate-Shen, 2010). Its gene, NKX3.1 often undergoes $\mathrm{LOH}$, often a consequence of whole-arm allelic deletion of $8 \mathrm{p}$, and is observed at high frequency in both ETS fusion-positive and -negative prostate cancers. Downregulation of Nkx3.1 appears early in prostate cancer and may act as a 'gatekeeper' event in cancer initiation (Baca et al, 2013). Although the incidence of $\mathrm{LOH}$ increases with tumour grade, the other allele remains unmutated with low levels of gene expression, leading to the speculation that epigenetic modification has a significant role in its downregulation (Shen and Abate-Shen, 2010).

The androgen receptor (AR) is a nuclear hormone receptor whose signalling is central to normal and cancerous prostate development (Shen and Abate-Shen, 2010). Blockade of the androgen pathway remains the mainstay of non-surgical treatment but only postpones the inevitable progression of disease. AR binding is implicated in tumour initiation through close proximity of AR-binding sites with re-arrangement break points (Berger et al, 2011), raising the possibility that distant genomic loci, bought together in close physical contact by AR complexes are re-arranged through transcriptional stress.

Genes believed to modulate AR activity and that are mutated in prostate cancer include the nuclear receptor co-activator 2 gene (NCOA2) and forkhead-box A1 (FOXA1). Mutations, as well as focal and non-focal gains have been detected in NCOA2 that were significantly correlated with elevated NCOA2 transcript levels (Taylor et al, 2010). Non-castrate patients with primary tumours harbouring NCOA2 mutation, overexpression or high-level amplification had significantly higher rates of recurrence (Taylor et al, 2010). FOXA1 is an AR cofactor that is recurrently mutated in both primary and metastatic tumours (Barbieri et al, 2012). FOXA1 expression has been demonstrated to increase cellular proliferation in the presence of androgen (Grasso et al, 2012), and may have a role in the progression of castrate-resistant prostate cancer. Other members of the forkhead-box family are located within regions that are recurrently deleted and a putative role as tumour suppressors has been suggested (Taylor et al, 2010).

There is a complex interaction between the AR and other signalling pathways, for instance the PI3K pathway. These interactions may help explain some mechanisms behind castrate resistance. The $A R$ itself undergoes gene amplification, point mutations and alteration in splicing leading to constitutively active variants. Amplification (46\% of samples) and point mutations ( $10 \%$ of samples) are reported in hormone refractory metastatic tumours but these are infrequently found in localised prostate cancer prior to implementation of therapy (Barbieri et al, 2012;
Grasso et al, 2012). These data infer that $A R$ aberrations are important as a mechanism for resistance to hormonal therapy (Visakorpi et al, 1995). Recent data have concluded that different tumour cell subclones within metastatic sites can carry independent mutations associated with castrate resistance (Gundem et al, 2015). Commonly, $A R$ copy number was demonstrated to have increased at separate time points implicating continuing selective pressure on the AR pathway. Furthermore, metastasis from half of the patients studied underwent polyclonal seeding with the transfer of multiple tumour clones between metastatic sites. In the majority of those patients, subclones carrying mechanisms associated with castration resistance were found to have re-seeded multiple sites.

\section{GENERIC PATHWAYS}

PI3K. PI3Ks are a family of enzymes involved in cellular functions such as cell growth, proliferation, differentiation, motility, survival and intracellular trafficking. Recurrent aberrations in the PI3K pathway, in particular the PTEN gene, reinforce its central importance in the pathogenesis of prostate cancer and confirm interest in its potential for targeted therapy.

PTEN acts by dephosphorylating lipid-signalling intermediates to deactivate PI3K-dependent signalling and its loss is associated with age and ETS-positive status (Steurer et al, 2014). Deletions at the PTEN gene locus occur in $\sim 40 \%$ of primary prostate cancers, and inactivating mutations occur in another 5-10\% (Barbieri et al, 2012; Grasso et al, 2012; Weischenfeldt et al, 2013). These events are more common in advanced disease (Taylor et al, 2010; Grasso et al, 2012), and a striking correlation between homozygous PTEN deletion and survival has been documented (Reid et al, 2010).

The membrane-associated guanylate kinase, WW and PDZ domain containing 2 (MAGI2) gene and Phosphatidylinositol-4,5bisphosphate 3-kinase, catalytic subunit alpha (PIK3CA) gene potentially also subvert PTEN and therefore PI3K activity. MAGI2 encodes a PTEN scaffolding protein that is recurrently disrupted by balanced re-arrangements without any evidence of copynumber loss (Berger et al, 2011). PIK3CA has been reported to undergo amplifications and activating point mutations in $\sim 25 \%$ and $5 \%$ of prostate cancers, respectively (Barbieri et al, 2012). These events appear anti-correlated with PTEN deletions, supporting the notion of functional redundancy due to similar mechanisms of action.

Cell cycle. Aberrations that drive uncontrolled cell cycling are central to oncogenesis. Here we briefly discuss the effects of mutations in genes that encode the retinoblastoma protein $(R B 1)$, the p53 protein (TP53) and the v-myc myelocytomatosis viral oncogene $(M Y C)$ in prostate cancer.

$\mathrm{RB1}$ is a tumour suppressor that checks cell cycle progression from the G1 to $S$ cell cycle phase, and is dysfunctional in many cancers. The $R B 1$ gene is more commonly deleted or mutated in castration-resistant prostate cancer (up to $45 \%$ of patients) than in clinically localised prostate cancer, and is coincident with the emergence of castrate-resistant disease (Taylor et al, 2010; Grasso et al, 2012).

The TP53 protein activates expression of the $\mathrm{p} 21^{\mathrm{WAF} 1}$ cyclindependent kinase inhibitor, regulating the cell cycle and acting as a classic tumour suppressor. In mouse models of prostate cancer, inactivation of TP53 is necessary to bypass the cellular senescence mechanisms that are activated upon the loss of PTEN (Chen et al, 2005). Aberrations in TP53 are recurrently seen in both clinically localised, as well as advanced cancer.

The MYC proto-oncogene encodes a transcription factor that causes oncogenesis through cycle progression and cell survival. Amplification and to a lesser extent, mutation of $M Y C$ are common in prostate cancer, although MYC is also often 
differentially expressed in the absence of any mutation (Shen and Abate-Shen, 2010; Taylor et al, 2010; Barbieri et al, 2012; Grasso et al, 2012). Often amplification is non-specific, involving a gain of the entire arm of chromosome 8 , such that this mutation may increase expression of other oncogenes to confer a growth advantage.

MAPK/ERK pathway. The MAPK/ERK pathway has a central role in many cancers, though its role in prostate cancer is less well established. The pathway is frequently perturbed in advanced prostate cancers (Taylor et al, 2010) and may enhance transcriptional activity of the AR. Activating mutations in KRAS and BRAF occur in roughly $10 \%$ of Asian patients but are rare in Caucasian men (Taylor et al, 2010; Barbieri et al, 2012; Grasso et al, 2012).

\section{CONCLUSIONS}

We have summarised common aberrations that contribute to the mutational landscape of human prostate cancer. The landscape encompasses inherited variants and mutational processes, differences in ETS family fusion-positive and -negative tumours, and the aberrations that may go on to cause metastatic and castrateresistant disease.

Significant challenges impeding the application of genomic medicine in prostate cancer include high levels of intra-tumoural heterogeneity and multifocality in primary tumours, and the often long natural history from diagnosis to metastasis or lethality. Both of these challenges hinder the generation of risk-stratification tools that correlate clinical outcomes with the genomic landscape. As structural variants contribute greatly to the genomic landscape, we envisage that multi-region whole-genome sequencing of hundreds of tumours will be required to better understand the natural evolution of prostate cancer. These methods may then pave the way to the generation of an affordable, prompt, genomic-based screening and treatment strategy from the clinic.

\section{ACKNOWLEDGEMENTS}

We thank U McDermott and J McLoughlin for comment and critical appraisal of this manuscript.

\section{REFERENCES}

Al Olama AA, Kote-Jarai Z, Berndt SI, Conti DV, Schumacher F, Han Y, Benlloch S, Hazelett DJ, Wang Z, Saunders E, Leongamornlert D, Lindstrom S, Jugurnauth-Little S, Dadaev T, Tymrakiewicz M, Stram DO, Rand K, Wan P, Stram A, Sheng X, Pooler LC, Park K, Xia L, Tyrer J, Kolonel LN, Le Marchand L, Hoover RN, Machiela MJ, Yeager M, Burdette L, Chung CC, Hutchinson A, Yu K, Goh C, Ahmed M, Govindasami K, Guy M, Tammela TL, Auvinen A, Wahlfors T, Schleutker J, Visakorpi T, Leinonen KA, Xu J, Aly M, Donovan J, Travis RC, Key TJ, Siddiq A, Canzian F, Khaw KT, Takahashi A, Kubo M, Pharoah P, Pashayan N, Weischer M, Nordestgaard BG, Nielsen SF, Klarskov P, Roder MA, Iversen P, Thibodeau SN, McDonnell SK, Schaid DJ, Stanford JL, Kolb S, Holt S, Knudsen B, Coll AH, Gapstur SM, Diver WR, Stevens VL, Maier C, Luedeke M, Herkommer K, Rinckleb AE, Strom SS, Pettaway C, Yeboah ED, Tettey Y, Biritwum RB, Adjei AA, Tay E, Truelove A, Niwa S, Chokkalingam AP, Cannon-Albright L, Cybulski C, Wokolorczyk D, Kluzniak W, Park J, Sellers T, Lin HY, Isaacs WB, Partin AW, Brenner H, Dieffenbach AK, Stegmaier C, Chen C, Giovannucci EL, Ma J, Stampfer M, Penney KL, Mucci L, John EM, Ingles SA, Kittles RA, Murphy AB, Pandha H, Michael A, Kierzek AM, Blot W, Signorello LB, Zheng W, Albanes D, Virtamo J, Weinstein S, Nemesure B, Carpten J, Leske C, Wu SY, Hennis A, Kibel AS, Rybicki BA, Neslund-Dudas C, Hsing AW, Chu L, Goodman PJ, Klein EA, Zheng SL, Batra J, Clements J, Spurdle A, Teixeira MR, Paulo P, Maia S, Slavov C, Kaneva R, Mitev V, Witte JS, Casey G, Gillanders EM,
Seminara D, Riboli E, Hamdy FC, Coetzee GA, Li Q, Freedman ML, Hunter DJ, Muir K, Gronberg H, Neal DE, Southey M, Giles GG, Severi G. Breast, Prostate Cancer Cohort CConsortium PConsortium CConsortium G-OECook MB, Nakagawa H, Wiklund F, Kraft P, Chanock SJ,

Henderson BE, Easton DF, Eeles RA, Haiman CA (2014) A meta-analysis of 87,040 individuals identifies 23 new susceptibility loci for prostate cancer. Nat Genet 46(10): 1103-1109.

Alexandrov LB, Nik-Zainal S, Wedge DC, Aparicio SA, Behjati S, Biankin AV, Bignell GR, Bolli N, Borg A, Borresen-Dale AL, Boyault S, Burkhardt B, Butler AP, Caldas C, Davies HR, Desmedt C, Eils R, Eyfjord JE, Foekens JA, Greaves M, Hosoda F, Hutter B, Ilicic T, Imbeaud S, Imielinski M, Jager N, Jones DT, Jones D, Knappskog S, Kool M, Lakhani SR, Lopez-Otin C, Martin S, Munshi NC, Nakamura H, Northcott PA, Pajic M, Papaemmanuil E, Paradiso A, Pearson JV, Puente XS, Raine K, Ramakrishna M, Richardson AL, Richter J, Rosenstiel P, Schlesner M, Schumacher TN, Span PN, Teague JW, Totoki Y, Tutt AN, Valdes-Mas R, van Buuren MM, van 't Veer L, Vincent-Salomon A, Waddell N, Yates LR. Australian Pancreatic Cancer Genome IConsortium IBCConsortium IMSPedBrain IZucman-Rossi J, Futreal PA, McDermott U, Lichter P, Meyerson M, Grimmond SM, Siebert R, Campo E, Shibata T, Pfister SM, Campbell PJ, Stratton MR (2013) Signatures of mutational processes in human cancer. Nature 500(7463): 415-421.

Baca SC, Prandi D, Lawrence MS, Mosquera JM, Romanel A, Drier Y, Park K, Kitabayashi N, MacDonald TY, Ghandi M, Van Allen E, Kryukov GV, Sboner A, Theurillat JP, Soong TD, Nickerson E, Auclair D, Tewari A, Beltran H, Onofrio RC, Boysen G, Guiducci C, Barbieri CE, Cibulskis K, Sivachenko A, Carter SL, Saksena G, Voet D, Ramos AH, Winckler W, Cipicchio M, Ardlie K, Kantoff PW, Berger MF, Gabriel SB, Golub TR, Meyerson M, Lander ES, Elemento O, Getz G, Demichelis F, Rubin MA, Garraway LA (2013) Punctuated evolution of prostate cancer genomes. Cell 153(3): 666-677.

Barbieri CE, Baca SC, Lawrence MS, Demichelis F, Blattner M, Theurillat JP, White TA, Stojanov P, Van Allen E, Stransky N, Nickerson E, Chae SS, Boysen G, Auclair D, Onofrio RC, Park K, Kitabayashi N, MacDonald TY, Sheikh K, Vuong T, Guiducci C, Cibulskis K, Sivachenko A, Carter SL, Saksena G, Voet D, Hussain WM, Ramos AH, Winckler W, Redman MC, Ardlie K, Tewari AK, Mosquera JM, Rupp N, Wild PJ, Moch H, Morrissey C, Nelson PS, Kantoff PW, Gabriel SB, Golub TR, Meyerson M, Lander ES, Getz G, Rubin MA, Garraway LA (2012) Exome sequencing identifies recurrent SPOP, FOXA1 and MED12 mutations in prostate cancer. Nat Genet 44(6): 685-689.

Berger MF, Lawrence MS, Demichelis F, Drier Y, Cibulskis K, Sivachenko AY, Sboner A, Esgueva R, Pflueger D, Sougnez C, Onofrio R, Carter SL, Park K, Habegger L, Ambrogio L, Fennell T, Parkin M, Saksena G, Voet D, Ramos AH, Pugh TJ, Wilkinson J, Fisher S, Winckler W, Mahan S, Ardlie K, Baldwin J, Simons JW, Kitabayashi N, MacDonald TY, Kantoff PW, Chin L, Gabriel SB, Gerstein MB, Golub TR, Meyerson M, Tewari A, Lander ES, Getz G, Rubin MA, Garraway LA (2011) The genomic complexity of primary human prostate cancer. Nature 470(7333): 214-220.

Cancer Research UK. Available at http://www.cancerresearchuk.org/cancerinfo/cancerstats/types/prostate/ (accessed on 22 December 2014).

Carver BS, Tran J, Gopalan A, Chen Z, Shaikh S, Carracedo A, Alimonti A, Nardella C, Varmeh S, Scardino PT, Cordon-Cardo C, Gerald W, Pandolfi PP (2009) Aberrant ERG expression cooperates with loss of PTEN to promote cancer progression in the prostate. Nature Genet 41(5): 619-624.

Chen Y, Wang J, Fraig MM, Metcalf J, Turner WR, Bissada NK, Watson DK, Schweinfest CW (2001) Defects of DNA mismatch repair in human prostate cancer. Cancer Res 61(10): 4112-4121.

Chen Z, Trotman LC, Shaffer D, Lin HK, Dotan ZA, Niki M, Koutcher JA, Scher HI, Ludwig T, Gerald W, Cordon-Cardo C, Pandolfi PP (2005) Crucial role of p53-dependent cellular senescence in suppression of Ptendeficient tumorigenesis. Nature 436(7051): 725-730.

Cooper CS, Eeles R, Wedge DC, Van Loo P, Gundem G, Alexandrov LB, Kremeyer B, Butler A, Lynch AG, Camacho N, Massie CE, Kay J, Luxton HJ, Edwards S, Kote-Jarai Z, Dennis N, Merson S, Leongamornlert D, Zamora J, Corbishley C, Thomas S, Nik-Zainal S, O’Meara S, Matthews L, Clark J, Hurst R, Mithen R, Bristow RG, Boutros PC, Fraser M, Cooke S, Raine K, Jones D, Menzies A, Stebbings L, Hinton J, Teague J, McLaren S, Mudie L, Hardy C, Anderson E, Joseph O, Goody V, Robinson B, Maddison M, Gamble S, Greenman C, Berney D, Hazell S, Livni N. the IPGFisher C, Ogden C, Kumar P, Thompson A, Woodhouse C, Nicol D, Mayer E, Dudderidge T, Shah NC, Gnanapragasam V, Voet T, Campbell P, Futreal A, Easton D, Warren AY, Foster CS, Stratton MR, Whitaker 
HC, McDermott U, Brewer DS, Neal DE (2015) Analysis of the genetic phylogeny of multifocal prostate cancer identifies multiple independent clonal expansions in neoplastic and morphologically normal prostate tissue. Nat Genet 47(4): 367-372.

Eeles R, Goh C, Castro E, Bancroft E, Guy M, Al Olama AA, Easton D, KoteJarai Z (2014) The genetic epidemiology of prostate cancer and its clinical implications. Nat Rev Urol 11(1): 18-31.

Grasso CS, Wu YM, Robinson DR, Cao X, Dhanasekaran SM, Khan AP, Quist MJ, Jing X, Lonigro RJ, Brenner JC, Asangani IA, Ateeq B, Chun SY, Siddiqui J, Sam L, Anstett M, Mehra R, Prensner JR, Palanisamy N, Ryslik GA, Vandin F, Raphael BJ, Kunju LP, Rhodes DR, Pienta KJ, Chinnaiyan AM, Tomlins SA (2012) The mutational landscape of lethal castrationresistant prostate cancer. Nature 487(7406): 239-243.

Gundem G, Van Loo P, Kremeyer B, Alexandrov LB, Tubio JM, Papaemmanuil E, Brewer DS, Kallio HM, Hognas G, Annala M, Kivinummi K, Goody V, Latimer C, O'Meara S, Dawson KJ, Isaacs W, Emmert-Buck MR, Nykter M, Foster C, Kote-Jarai Z, Easton D, Whitaker HC. Group IPUNeal DE, Cooper CS, Eeles RA, Visakorpi T, Campbell PJ, McDermott U, Wedge DC, Bova GS (2015) The evolutionary history of lethal metastatic prostate cancer. Nature 520(7547): 353-357.

Hieronymus H, Schultz N, Gopalan A, Carver BS, Chang MT, Xiao Y, Heguy A, Huberman K, Bernstein M, Assel M, Murali R, Vickers A, Scardino PT, Sander C, Reuter V, Taylor BS, Sawyers CL (2014) Copy number alteration burden predicts prostate cancer relapse. Proc Natl Acad Sci USA 111(30): 11139-11144.

Hjelmborg JB, Scheike T, Holst K, Skytthe A, Penney KL, Graff RE, Pukkala E, Christensen K, Adami HO, Holm NV, Nuttall E, Hansen S, Hartman M, Czene K, Harris JR, Kaprio J, Mucci LA (2014) The heritability of prostate cancer in the Nordic Twin Study of Cancer. Cancer Epidemiol Biomarkers Prev 23(11): 2303-2310.

Hong MK, Macintyre G, Wedge DC, Van Loo P, Patel K, Lunke S, Alexandrov LB, Sloggett C, Cmero M, Marass F, Tsui D, Mangiola S, Lonie A, Naeem H, Sapre N, Phal PM, Kurganovs N, Chin X, Kerger M, Warren AY, Neal D, Gnanapragasam V, Rosenfeld N, Pedersen JS, Ryan A, Haviv I, Costello AJ, Corcoran NM, Hovens CM (2015) Tracking the origins and drivers of subclonal metastatic expansion in prostate cancer. Nature Commun 6 : 6605.

King JC, Xu J, Wongvipat J, Hieronymus H, Carver BS, Leung DH, Taylor BS, Sander C, Cardiff RD, Couto SS, Gerald WL, Sawyers CL (2009) Cooperativity of TMPRSS2-ERG with PI3-kinase pathway activation in prostate oncogenesis. Nat Genet 41(5): 524-526.

Kluth M, Hesse J, Heinl A, Krohn A, Steurer S, Sirma H, Simon R, Mayer PS, Schumacher U, Grupp K, Izbicki JR, Pantel K, Dikomey E, Korbel JO, Plass C, Sauter G, Schlomm T, Minner S (2013) Genomic deletion of MAP3K7 at 6q12-22 is associated with early PSA recurrence in prostate cancer and absence of TMPRSS2:ERG fusions. Mod Pathol 26(7): 975-983.

Krohn A, Seidel A, Burkhardt L, Bachmann F, Mader M, Grupp K, Eichenauer T, Becker A, Adam M, Graefen M, Huland H, Kurtz S, Steurer S, Tsourlakis MC, Minner S, Michl U, Schlomm T, Sauter G, Simon R, Sirma H (2013) Recurrent deletion of 3p13 targets multiple tumour suppressor genes and defines a distinct subgroup of aggressive ERG fusion-positive prostate cancers. J Pathol 231(1): 130-141.

Lawrence MS, Stojanov P, Mermel CH, Robinson JT, Garraway LA, Golub TR, Meyerson M, Gabriel SB, Lander ES, Getz G (2014) Discovery and saturation analysis of cancer genes across 21 tumour types. Nature 505(7484): 495-501.

Lichtenstein P, Holm NV, Verkasalo PK, Iliadou A, Kaprio J, Koskenvuo M, Pukkala E, Skytthe A, Hemminki K (2000) Environmental and heritable factors in the causation of cancer-analyses of cohorts of twins from Sweden, Denmark, and Finland. N Engl J Med 343(2): 78-85.

Lindberg J, Klevebring D, Liu W, Neiman M, Xu J, Wiklund P, Wiklund F, Mills IG, Egevad L, Gronberg H (2013) Exome sequencing of prostate cancer supports the hypothesis of independent tumour origins. Eur Urol 63(2): 347-353.

Massie CE, Lynch A, Ramos-Montoya A, Boren J, Stark R, Fazli L, Warren A, Scott H, Madhu B, Sharma N, Bon H, Zecchini V, Smith DM, Denicola GM, Mathews N, Osborne M, Hadfield J, Macarthur S, Adryan B, Lyons SK, Brindle KM, Griffiths J, Gleave ME, Rennie PS, Neal DE, Mills IG (2011) The androgen receptor fuels prostate cancer by regulating central metabolism and biosynthesis. EMBO J 30(13): 2719-2733.
Raymond VM, Mukherjee B, Wang F, Huang SC, Stoffel EM, Kastrinos F, Syngal S, Cooney KA, Gruber SB (2013) Elevated risk of prostate cancer among men with Lynch syndrome. J Clin Oncol 31(14): 1713-1718.

Reid AH, Attard G, Ambroisine L, Fisher G, Kovacs G, Brewer D, Clark J, Flohr P, Edwards S, Berney DM, Foster CS, Fletcher A, Gerald WL, Moller H, Reuter VE, Scardino PT, Cuzick J, de Bono JS, Cooper CS. Transatlantic Prostate G (2010) Molecular characterisation of ERG, ETV1 and PTEN gene loci identifies patients at low and high risk of death from prostate cancer. $\mathrm{Br} J$ Cancer 102(4): 678-684.

Shen MM, Abate-Shen C (2010) Molecular genetics of prostate cancer: new prospects for old challenges. Genes Dev 24(18): 1967-2000.

Steurer S, Mayer PS, Adam M, Krohn A, Koop C, Ospina-Klinck D, Tehrani AA, Simon R, Tennstedt P, Graefen M, Wittmer C, Brors B, Plass C, Korbel J, Weischenfeldt J, Sauter G, Huland H, Tsourlakis MC, Minner S, Schlomm T (2014) TMPRSS2-ERG fusions are strongly linked to young patient age in low-grade prostate cancer. Eur Urol 66(6): 978-981.

Svensson MA, LaFargue CJ, MacDonald TY, Pflueger D, Kitabayashi N, Santa-Cruz AM, Garsha KE, Sathyanarayana UG, Riley JP, Yun CS, Nagy D, Kosmeder JW, Pestano GA, Tewari AK, Demichelis F, Rubin MA (2011) Testing mutual exclusivity of ETS rearranged prostate cancer. Lab Invest 91(3): 404-412.

Taylor BS, Schultz N, Hieronymus H, Gopalan A, Xiao Y, Carver BS, Arora VK, Kaushik P, Cerami E, Reva B, Antipin Y, Mitsiades N, Landers T, Dolgalev I, Major JE, Wilson M, Socci ND, Lash AE, Heguy A, Eastham JA, Scher HI, Reuter VE, Scardino PT, Sander C, Sawyers CL, Gerald WL (2010) Integrative genomic profiling of human prostate cancer. Cancer Cell 18(1): 11-22.

Theurillat JP, Udeshi ND, Errington WJ, Svinkina T, Baca SC, Pop M, Wild PJ, Blattner M, Groner AC, Rubin MA, Moch H, Prive GG, Carr SA, Garraway LA (2014) Prostate cancer. Ubiquitylome analysis identifies dysregulation of effector substrates in SPOP-mutant prostate cancer. Science 346(6205): 85-89.

Tomlins SA, Bjartell A, Chinnaiyan AM, Jenster G, Nam RK, Rubin MA, Schalken JA (2009) ETS gene fusions in prostate cancer: from discovery to daily clinical practice. Eur Urol 56(2): 275-286.

Tomlins SA, Laxman B, Dhanasekaran SM, Helgeson BE, Cao X, Morris DS, Menon A, Jing X, Cao Q, Han B, Yu J, Wang L, Montie JE, Rubin MA, Pienta KJ, Roulston D, Shah RB, Varambally S, Mehra R, Chinnaiyan AM (2007) Distinct classes of chromosomal rearrangements create oncogenic ETS gene fusions in prostate cancer. Nature 448(7153): 595-599.

Visakorpi T, Hyytinen E, Koivisto P, Tanner M, Keinanen R, Palmberg C, Palotie A, Tammela T, Isola J, Kallioniemi OP (1995) In vivo amplification of the androgen receptor gene and progression of human prostate cancer. Nat Genet 9(4): 401-406.

Weischenfeldt J, Simon R, Feuerbach L, Schlangen K, Weichenhan D, Minner S, Wuttig D, Warnatz HJ, Stehr H, Rausch T, Jager N, Gu L, Bogatyrova O, Stutz AM, Claus R, Eils J, Eils R, Gerhauser C, Huang PH, Hutter B, Kabbe R, Lawerenz C, Radomski S, Bartholomae CC, Falth M, Gade S, Schmidt M, Amschler N, Hass T, Galal R, Gjoni J, Kuner R, Baer C, Masser S, von Kalle C, Zichner T, Benes V, Raeder B, Mader M, Amstislavskiy V, Avci M, Lehrach H, Parkhomchuk D, Sultan M, Burkhardt L, Graefen M, Huland H, Kluth M, Krohn A, Sirma H, Stumm L, Steurer S, Grupp K, Sultmann H, Sauter G, Plass C, Brors B, Yaspo ML, Korbel JO, Schlomm T (2013) Integrative genomic analyses reveal an androgen-driven somatic alteration landscape in early-onset prostate cancer. Cancer Cell 23(2): 159170 .

Williams JL, Greer PA, Squire JA (2014) Recurrent copy number alterations in prostate cancer: an in silico meta-analysis of publicly available genomic data. Cancer Genet 207(10-12): 474-488.

Zack TI, Schumacher SE, Carter SL, Cherniack AD, Saksena G, Tabak B, Lawrence MS, Zhang CZ, Wala J, Mermel CH, Sougnez C, Gabriel SB, Hernandez B, Shen H, Laird PW, Getz G, Meyerson M, Beroukhim R (2013) Pan-cancer patterns of somatic copy number alteration. Nat Genet 45(10): 1134-1140.

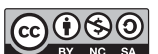

This work is licensed under the Creative Commons Attribution-Non-Commercial-Share Alike 4.0 International License. To view a copy of this license, visit http:// creativecommons.org/licenses/by-nc-sa/4.0/ 